\title{
HEMATO-BIOCHEMICAL RESPONSE TO EXERCISE WITH ERGOMETRIC TREADMILL, MOUNT TRAINING AND COMPETITION IN JUMPING HORSES
}

\author{
Valesca Peter Dos Santos, Felix Diaz Gonzalez, Jarbas Francisco da Costa Castro Jr, \\ Tiane Ferreira Castro Correio ${ }^{1}$ \\ ${ }^{1}$ E-mail to: Carina Scheree: tianefcastro@yahoo.com.br
}

RESUMO: Este estudo objetivou avaliar as variações hematológicas e bioquímicas que ocorrem em diferentes protocolos de exercícios em equinos de salto. Foram utilizados 17 equinos da raça de salto Brasileiro de Hipismo, entre 5 e 12 anos. Todos os animais foram submetidos aos seguintes protocolos de exercício: repouso (controle); esteira ergométrica ( $40 \mathrm{~min}$ a $5 \mathrm{~m} / \mathrm{s}$ ); treinamento montado (40 min, sendo $10 \mathrm{~min}$ ao passo, $20 \mathrm{~min}$ ao trote, 10 min ao galope); e competição (prova de salto a $350 \mathrm{~m} / \mathrm{min}$, obstáculos com 1,20 m de altura e percurso de $430 \mathrm{~m}$ ). Foram realizadas coletas de sangue e verificação da frequência cardíaca com os animais em repouso (controle) e imediatamente após o término dos protocolos de exercício. As avaliações sanguíneas abrangeram contagem de eritrócitos e leucócitos totais, hematócrito, concentração de hemoglobina, proteínas plasmáticas totais, creatina quinase (CK), lactato desidrogenase (LDH), aspartato transaminase (AST), fosfatase alcalina (FA), lactato, glicose, bicarbonato, ureia, creatinina, sódio e potássio. Em relação ao grupo controle, o exercício em esteira ergométrica apresentou variações significativas apenas em hematócrito, frequência cardíaca, potássio e creatinina. $O$ treinamento montado e a competição apresentaram aumentos nas concentrações de proteína, CK, LDH, FA e potássio com relação aos demais protocolos de exercício. Hemoglobina e lactato aumentaram apenas no grupo de competição. A concentração de glicose reduziu em todos os grupos experimentais quando comparada ao grupo em repouso. A frequência cardíaca, a creatinina, número de eritrócitos, hematócrito e FA apresentaram aumento progressivo conforme a intensidade de exercício. Não houve alterações nos valores de AST, ureia e sódio. Conclui-se que os diferentes protocolos de exercício em equinos de salto promoveram diferentes respostas nos parâmetros hematobioquímicos.

Palavras-chave: enzimas clínicas; fisiologia do exercício

\begin{abstract}
The aim of this study was to evaluate the variations promoted by different kinds of exercise on hematological and biochemical parameters of jumping horses. Seventeen Brazilian Jumping horses (Brasileiro de Hipismo breed) from 5 to 12 years old were used. All animals were submitted to the following exercise protocols: rest (control group), ergometric treadmill (40 minutes at a speed of $5 \mathrm{~m} / \mathrm{s}$ ), mount training (40 minutes consisting of 10 minutes walking, 20 minutes trotting and 10 minutes running on field conditions) and jumping competition (speed of $350 \mathrm{~m} / \mathrm{min}$, height of obstacles $1.20 \mathrm{~m}$ and $430 \mathrm{~m}$ length). Venous blood samples were drawn from the jugular vein and heart rate were verified at rest (control) and immediately after the exercise. The erythrocyte and leucocytes count, packed cell volume, hemoglobin concentration, creatine kinase (CK), aspartate aminotransferase (AST), lactate dehydrogenase (LDH), alkaline phosphatase (ALP), sodium, potassium, bicarbonate, total plasma protein (TPP), urea, creatinine were determined. The treadmill group showed higher values of PCV, heart rate and creatinine compared to control group. Mount training group and jump group promoted an increase of total protein, CK, LDH, ALP, lactate, creatinine and potassium. Hemoglobin and lactate increase only in jump competition. Glucose concentration decreased in all groups of exercise practice. Heart rate, erythrocyte counting, PCV, ALP and creatinine increased in a positively relation with the exercise intensity. No alterations were observed in AST, urea and sodium. It is concluded that different exercise protocols in jumping horses promoted different responses on hemato-biochemical parameters.
\end{abstract}

Key Words: clinical enzymes; exercise physiology 


\section{INTRODUÇÃO}

In the last years the interest for exercise physiology in horses has been growing in the search for a better knowledge on the responses to several types of exercises (Sabev, 2011). However, many gaps in this subject still remain to know in the perspective to obtain evaluation tools for training techniques (Kowal et al., 2006).

Early works concerning exercise and training evaluation in horses only considered total blood count, but thereafter biochemistry parameters were included in the performance study of the athlete horse (McKenzie et al., 2014). Analysis of hematological and biochemical parameters are useful during training for driving the intensity and the type of the effort appropriate to the athletic capacity of each animal.

The use of ergometric treadmill in horses took along several advantages not only in diagnosis aspects, but also as an important support during training activities (McGowan et al., 2002; Prince et al., 2002). Ergonometric treadmill allows a better study of the impact promoted by a determined exercise pattern, as it can be measured speed, constancy and duration of the exercise (Seeherman, 1991).

The present study evaluates the use of common techniques of training in ergometric treadmill, in traditional exercise and in competition through the variations observed in hematological and biochemical parameters in jumping horses.

\section{MATERIAL E MÉTODOS}

In this work seventeen jumping horses of both sexes and with ages between 5 to 12 years were submitted to three different situations of exercises. All the animals were trained to the practice of traditional and treadmill exercise, mounting exercise and competitions.
The horses were maintained in stables belonging to an equestrian society in Porto Alegre (southern Brazil), feeding a commercial concentrate twice a day, supplemented with hay and having water ad libitum. All the horses were clinically evaluated and only healthy animals participated in the experiment. All the animals were submitted to each one of the following treatments: (1) Rest: maintained resting in the stable for at least 24 hours (control group). (2) Ergometric treadmill (Equiboard model ET01, São Paulo, Brazil): training exercise with slope of $0 \square$ for 40 minutes and constant speed of $5 \mathrm{~m} / \mathrm{s}$; (3) Traditional mount training during 40 minutes (10 minutes walking, 20 minutes trotting and 10 minutes running on field conditions) e (4) Competition: jumping competition at a mean speed of 350 $\mathrm{m} / \mathrm{min}$, obstacles with $1.20 \mathrm{~m}$ height and extension of $430 \mathrm{~m}$. The interval among each treatment was at least 12 days. The experiment was performed during the spring season,when the historical environmental temperature of Porto Alkegre presents intervals from $15^{\circ} \mathrm{C}$ to $30^{\circ} \mathrm{C}$ and relative humidity between 65 to $80 \%$.

During rest and immediately after finishing the treatments, heart rate was measured in all animals using a cardiac monitor (Datascope model Passport 2, The Physician's Resouce for Medical Equipment, USA). Blood samples were taken from the jugular vein using in vacuum tubes with sodium fluoride for determining glucose and lactate, vacuum tubes with EDTA for total blood count and bicarbonate, vacuum plain tubes for determining enzymes (AST, ALP, LDH and CK), electrolytes ( $\mathrm{Na}, \mathrm{K})$, urea and creatinine.

Blood counting includes packed cell volume (PCV) obtained by microhematocrit technique (Jain, 1986), hemoglobin by the cyanometahemoglobin method, and erythrocyte and leukocyte counting by 
microscopy Neubauer chamber, using as diluents Hayem solution for erythrocyte counting and Türk solution for leukocyte counting with magnification of $1: 200$ and $1: 20$, respectively. Total protein was determined by refractometry and determination of CK, AST, LDH, ALP, lactate, glucose, urea and creatinine were done by colorimetric techniques using Cobas Integra (Roche). Sodium and potassium were determined by potenciometry using selective electrodes (Integra 400, Roche). Bicarbonate concentration was obtained by gasometry (Rapidlab 348 , Bayer).

The statistical analysis included one-way Anova for repeated measures among groups and variables differences compared using the Tukey test. The considered level of probability was $5 \%$.

\section{RESULTS}

The values of the hematological and biochemical parameters of the jumping horses in the exercise protocols are showed in Table 1. Erythrocyte counts increased significantly with the increment of the exercise effort. The same tendency was observed with PCV values. The difference between PCV at rest and in competition was tenfold increase. Hemoglobin concentration was higher only in the competition group. Leukocyte counting did not show any difference among the groups. Heart rate increased proportionally with the exercise intensity. The heart rate value of the horses in competition was fivefold increase compared with the values at rest. Table 1. Hematological and biochemical parameters in jumping horses immedistely after being
iubmitted to different types of exercise: ergometrictreadmill ( $40 \mathrm{~min})$, mount t $\mathrm{sin}$ ing $(40 \mathrm{~min})$ and jump competition. The values are expressed as mean \pm standard devistion. In all cases $\mathrm{N}=17$. $\begin{array}{lllll}\text { Parameter } & \text { Rest } & \text { Ergometric } & \text { Mount } & \text { Jump } \\ \text { (control) } & & \text { treadmill } & \text { training } & \text { competition }\end{array}$ $\begin{array}{lcccc} & \text { (control) } & \text { treadmill } & \text { training } & \text { competition } \\ \text { Heartrate (bpm) } & 35.6^{2} \pm 3.5 & 60.0^{\circ} \pm 16 & 124.0^{\circ} \pm 8 & 184.3^{\mathrm{s}} \pm 8.3\end{array}$ Erythrocytes $\left(10^{\circ} / \mathrm{mL}\right) \quad 8.18^{*} \pm 0.73 \quad 8.55^{\circ} \pm 0.54 \quad 8.84^{\circ} \pm 0.69 \quad 9.54 \pm 1.28$

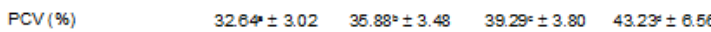
Hemoglobin $(g / d L) \quad 12.3^{*} \pm 1.43 \quad 11.24^{*} \pm 1.32 \quad 12.91^{*} \pm 1.16 \quad 14.075 \pm 1.88$ Leukocytes ( $(\mu \mathrm{L}) \quad 8,217 \pm 1,216 \quad 8,300 \pm 1,107 \quad 7,988 \pm 1,462 \quad 8,241 \pm 1,450$ Total protein $(g / L) \quad 60.1^{*} \pm 3.5 \quad 58.7^{*} \pm 3.4 \quad 68.6^{*} \pm 4.2 \quad 08.7 \pm \pm 4.7$ CK (U/L) $\quad 64.3^{*} \pm 16.2 \quad 77.6^{*} \pm 30.6 \quad 103.0^{\circ} \pm 34.1 \quad 91.75 \pm 42.2$ LDH (U/L) $\quad 224.2^{2} \pm 75.4 \quad 249.1^{*} \pm 142.8 \quad 262.0^{5} \pm 79.0 \quad 201.3^{*} \pm 47.3$ $\begin{array}{lllll}\text { AST (U/L) } & 144.5 \pm 53.3 & 143.7 \pm 40.8 & 125.2 \pm 17.8 & 128.7 \pm 34.0\end{array}$ ALP (U/L) $\quad 109.5^{*} \pm 34.0 \quad 100.0^{*} \pm 20.5 \quad 143.9^{\circ} \pm 28.9 \quad 150 . \theta^{*} \pm 37.1$ Lactate (mmoll $) \quad 0.60^{*} \pm 0.15 \quad 0.63 \pm 0.12 \quad 0.50^{*} \pm 0.17 \quad 3.14 \pm 1.93$ Glucose (mmol L) $\quad 5.48^{x} \pm 0.662 \quad 4.81^{\circ} \pm 0.578 \quad 4.53^{\circ} \pm 0.741 \quad 4.98^{\circ} \pm 1.12$ Bicarbonate (mmol $\mathrm{L}) \quad 22.8 \pm 1.8 \quad 23.9 \pm 2.8 \quad 22.0 \pm 5.2 \quad 22.5 \pm 4.2$ $\begin{array}{lllll}\text { Urea (mmoll L) } & 6.50 \pm 1.93 & 6.58 \pm 1.92 & 6.29 \pm 1.32 & 6.32 \pm 1.15\end{array}$ Creatinine $(\mu \mathrm{mol} / \mathrm{L}) \quad 107.8^{*} \pm 6.2 \quad 1123^{*} \pm 4.4 \quad 137.0^{\circ} \pm 15.9 \quad 140.5^{*} \pm 13.2$ Sodium(mmoVL) $\quad 136.29 \pm 3.58 \quad 138.4 \pm 4.22 \quad 138.12 \pm 2.64 \quad 138.29 \pm 3.58$ \begin{tabular}{lrrrr} 
Potas sium (mmoll $)$ & $3.55^{5} \pm 0.29$ & $3.81^{ \pm} \pm 0.52$ & $4.10^{3} \pm 0.22$ & $4.09^{\circ} \pm 0.43$ \\
\hline Different
\end{tabular} cell volume, CK: oreatine kinase, AST: as pertate aminotransferase, ALP: alk sline phos phatase, LDH: lactate des hydrogenase.

Total protein values were higher in the groups of training and competition, compared with the groups at rest and treadmill. The CK activity was greater in the mount training group compared with the competition group, and the treadmill exercise did not differ from the horses at rest. The animals in mount training had the highest values of LDH. The AST activity did not vary among all types of exercises. The ALP activity was higher in horses submitted to mount training and competition, compared with the animals at rest and in treadmill exercise.

The concentration of lactate was greater only in the competition group which had fivefold increase in relation to the other groups. The glycemia values were higher in the horses at rest compared with the animals submitted to exercise. Bicarbonate, sodium and urea values did not differ in any group. Creatinine values had an increase which was gradual with the intensity of exercise. Potassium values were higher in the horses submitted to mount training and competition compare with the animals at rest or in the ergometric treadmill. 


\section{DISCUSSION}

The present work compares different exercise protocols with focus on hemato-biochemical changes in jumping horses. The exercises had a progressive intensity (ergometric treadmill $\rightarrow$ mount training $\rightarrow$ jump competition) having the rest condition as control group. Heart rate evaluation confirms the progressive intensity of the exercise protocols. The progressive increments of the exercises were similar to those detected by Voss et al. (2002) and Sabev (2011).

Erythrocyte counting and PCV significantly augmented with the exercise intensity, with higher values in jump competition. Even though Ferraz et al. (2009) mentioned that PCV increases with the intensity of the exercise, as a consequence of hemoconcentration caused by dehydration, and erythrocyte counting augments in response to spleen contraction, the results of the present work clearly show that jump competition demands higher circulation of blood red cells, compared to training (mounted or treadmill). Hemoglobin values were significantly higher only in the jump competition group. AguileraTejero et al. (2000) found a hemoglobin increment in horses after intensive exercise varying from $11.8 \pm 0.5 \mathrm{~g} / \mathrm{dL}$ at rest to $18.0 \pm 0.6 \mathrm{~g} / \mathrm{dL}$. Hemoglobin increase is a physiological response to exercise in order to increase the tissue oxygenation capacity of the blood (Rose et al., 1980). The present results suggest that erythrocyte counting and PCV seem to be more sensible indicators that respond to moderate exercise, while hemoglobin is an indicator that responds to more intense exercise.

Leukocyte counting did not show any difference among groups, in contrast with the findings of Ferraz et al. (2009), who observed increase of total leukocytes in horses at rest $(8,730 \pm$ $360 / \mu \mathrm{L})$ compared with horses after exercise $(11,280 \pm 520 / \mu \mathrm{L})$. This increment was attributed to catecholamine's action released after vigorous exercise. However, this is a transitory effect with a maximum duration of 30 min (Paludo et al., 2002) and was not observed in the present experiment.

Total protein concentration was higher in horses submitted to mounting exercise and to jump competition, compared to horses at rest or in treadmill exercise. Rose et al. (1980) also found an increase of total protein in horse (from $68.0 \pm 4.7 \mathrm{~g} / \mathrm{L}$ before exercise to $73.1 \pm 6.2 \mathrm{~g} / \mathrm{L}$ after jump competition), attributed to a moderated degree of dehydration.

Activities of muscular enzymes, namely creatine kinase (CK), aspartate transaminase (AST) and lactate dehydrogenase (LDH) have been used as indicators of muscle lesions (Balarin et al., 2005). In the case of CK, some transient increments have been observed after exercise due to higher permeability membrane without any muscle lesion (Gondin et al., 2013). CK activity was higher in the groups of mounting exercise and jump competition compared to rest and treadmill groups. Those findings agreed with data observed by Andrews et al. (1995) and Robinson (2003). CK response in athletic horses depends on training condition, being higher in animals in initial phase of training and in harder and longer exercises (Harris et al., 1998). In polo ponies, Ferraz et al. (2010) found plasma CK increments of $35 \%$ after 6 hours of a training match returning to baseline after $12 \mathrm{~h}$. Those authors suggest a period of $24 \mathrm{~h}$ after a physical effort to clinically evaluate $\mathrm{CK}$ values in athletic horses, considering that this enzyme has a plasma half-life of $6 \mathrm{~h}$.

$\mathrm{LDH}$ in horses at rest diminished in a progressive way as training condition of the animals is more advanced (McKenzie et al., 2014). In 
those animals, low increase due to exercise might be observed. In the present work LDH was higher only in the mounting group, which is unexpected considering that the jump competition is a harder exercise. Anyway, the relatively low LDH increase in more severe exercises revealed a good physical conditioning of the animals. McGowan et al. (2002) also did not find differences in $\mathrm{LDH}$ values in horses submitted to treadmill exercises.

Values of AST were not different among groups in the present study, which is a characteristic of a good athletic condition in animals submitted to exercise (Harris et al., 1998). Andrews et al. (1995) found that AST activity increases after a three day long competition compared to values at rest and Snow et al. (1982) observed moderate increment in AST after an endurance riding of $80 \mathrm{~km}$, attributed to dehydration and intravascular hemolysis. Those findings revealed that AST activity may be augmented in cases of extreme exercise demand in well conditioned horses. Lack of increment responses in plasma enzymes may be due to moderated exercise and increased values due to exercise generally return to their basal levels after $30 \mathrm{~min}$ at rest (Thomassian et al., 2007, McGowan, 2008).

Alkaline phosphatase (ALP) activity was higher in mounting and competition groups. Rose et al. (1980) and Williamson et al. (1996) reported increases in ALP in horses participating of endurance riding, suggesting that the intensity of the exercise lead to fluid losses.

Although many works show increments in plasma enzymes after exercises of several degrees of intensity, in general, those increments may reach $50 \%$ of baseline and remain within the reference limits. Marked enzyme increments have been observed only in horses with suspected pathologic muscle damage (McGowan, 2008).

Lactate is an important indicator of exercise performance (Pösö, 2002), because adapted animals have more stability of serum concentrations than non-adapted animals. Alterations in the values of serum lactate may indicate fatigue as a consequence of an increased anaerobic muscle catabolism during exercise (McGowan et al., 2002). In the present experiment, animals training on treadmill or mounting exercise did not have increments in lactate, but after jump competition, the serum concentration was 5 fold the mean of the other groups $(P<0.05)$, indicating the intensity of the exercise. Guhl et al. (1996) found a positive correlation between lactate concentration and intensity of training and Thomassian et al. (2005) detected lactate alterations in horses trained at speed higher than $8 \mathrm{~m} / \mathrm{s}$ (in the present experiment speed in treadmill was 5 $\mathrm{m} / \mathrm{s}$ ). Ferraz et al. (2010) found an increment of 29 fold in plasma lactate of ponies submitted to a training match compared to the resting situation, however returning to the baseline after 6 $\mathrm{h}$ post-exercise. This variation in plasma lactate demonstrates that the aerobic condition might recover few hours after severe exercise.

Glucose concentration in serum reduced after exercise in all the groups of this experiment, as a consequence of energy demand and depletion of hepatic glucose. More intense or longer exercises as endurance riding or complete races may cause hyperglycemia (Fernandes and Larsson, 2000), which is considered a physiological response.

Bicarbonate concentrations in all groups of exercised horses were within the physiological range (Robinson, 2003) without any difference in relation to the rest group. This finding was surprising in the jump competition group, 
as an increase in lactate may result in acidosis (Aguilera-Tejero et al., 2000). It is probable that lactate increase may be less drastic than trotting or gallop because the lower duration of jumping competition. In addition, the stability of bicarbonate may result from an adequate compensation or physical adaptation of the animals (Foreman et al., 1996).

Serum urea also did not show alterations with exercise in the horses of this experiment, similarly to the finding of Fernandes et al. (2010) with Thoroughbred horses submitted to exercise. In contrast, creatinine values increased in a progressive manner according to the intensity of exercise, in agree to the observed by Fernandes et al (2010). This phenomenon may be explained by a reduction in the plasma volume and an increase in the muscle protein catabolism (Rose et al., 1980). The rise in creatinine occurs before any rise in urea because urea excretion by kidney is significantly reduced during exercise.

Sodium concentrations did not vary among groups of horses, as in the work of Fernandes et al. (2010) studying horses submitted to different intensity exercises. Matsui et al. (2002) found sodium losses of $23 \%$ of mineral requirements through sweat in horses submitted to intense exercise, but they suggest that an additional sodium supplement is not necessary to compensate such losses. Crocomo et al. (2009) found serum sodium decreases in Thoroughbred horses after intense exercise attributed the sodium sweat losses. Aguilera-Tejero et al. (2000) observed rise in sodium after a jump competition, as a consequence of water loss, confirmed by hyperproteinemia. It seems that hypernatremia will occur only in more intense and longer exercises, as it was observed in ponies submitted to high intensity effort (Ferraz et al., 2010).
Potassium behavior was different than sodium. Higher values of potassium were found in horses submitted to mounting exercise and jump competition, compared to rest and treadmill groups. Aguilera-Tejero et al. (2000) and Piccione et al. (2007) mentioned that potassium increase may occur in intense exercise as a consequence of dehydration and may accompany the increment in total protein, as observed in the present work. Schott et al. (2002) cited that increase in potassium may be due, not only to plasma volume reduction, but also to cation exchange from inner cell fluid in lactate metabolic acidosis compensation.

\section{CONCLUSION}

It is concluded that physical exercise intensity cause different hemato-biochemical alterations in jump horses. Erythrocytes, PCV, ALP, creatinine and heart rate increase progressively with the exercise intensity. Hemoglobin and lactate increase only in jump competition. Total protein, CK and potassium increase in mounting exercise and jump competition. Glucose decreases in all the exercise protocols, while no alterations are observed in AST, urea and sodium.

\section{NOTE}

The research was approved by the Ethical Committee of the Federal University of Rio Grande do Sul (Project no 9934).

\section{REFERÊNCIAS}

AGUILERA-TEJERO, E.; ESTEPA, J.C; LOPEZ, I. et al. Quantitative analysis of acid-base balance in show jumpers before and after exercise. Research in Veterinary Science, v.68, n.2., p.103-108, 2000. 
ANDREWS, F.M.; GEISER, D.R.; WHITE,S.L. et al. Hematological and biochemical changes in horses competing in a 3 star horse trial and 3day-event. Equine Veterinary Journal, suppl.20, p.57-63, 1995.

BALARIN, M.R.S.; LOPES, R.S.L.; KOHAYAGAWA, A. et al. Avaliação da glicemia e da atividade sérica de aspartato aminotransferase, creatinoquinase, gamaglutamiltransferase e lactato desidrogenase em equinos puro sangue inglês (PSI) submetidos a exercícios de diferentes intensidades. Semina: Ciências Agrárias, v.26, n.2, p.211-218, 2005.

CROCOMO, L.F.; BALARIN, M.R.S.;

TAKAHIRA, R.K. et al. Macrominerais séricos em equinos atletas da raça Puro Sangue Inglês, antes e após exercício físico de alta intensidade. Revista Brasileira de Saúde e Produção Animal, v.10, n.4, p.929-938, 2009.

FERRAZ, G.C.; TEIXEIRA NETO, A.R.; D'ANGELIS, F.H.F. et al. Alterações hematológicas e cardíacas em cavalos Árabes submetidos ao teste de esforço crescente em esteira rolante. Brazilian Journal of Veterinary Research and Animal Science, v.46, n.6, p.431437, 2009.

FERRAZ, G.C.; SOARES, O.A.B.; FOZ, N.S.B. et al. The workload and plasma ion concentration in a training match session of high-goal (elite) polo ponies. Equine Veterinary Journal, v. 42, suppl. 38, p.191-195, 2010.

FERNANDES, W.R.; LARSSON, M.H.M.A. Alterações nas concentrações séricas de glicose, sódio, potássio, uréia e creatinina em equinos submetidos a provas de enduro de 30 $\mathrm{km}$ com velocidade controlada. Ciência Rural, v.30, n.3, p.393-398, 2000.

FERNANDES, W.R.; DOMINGUES JUNIOR, M.; TOLEDO, P.S. et al. Avaliação dos níveis séricos de uréia, creatinina, sódio e potássio em cavalos da raça PSI submetidos a exercícios de diferentes intensidades. Veterinária e Zootecnia, v.17, n.3, p.359-366, 2010.

FOREMAN, J.H.; GRUBB, T.L.; BENSON, G.J. et al. Acid-base and electrolyte effects of shortening steeplechase in a three-day-event. Equine Veterinary Journal, suppl.22, p. 85-90, 1996.

GUHL, A.; LINDNER, A.; VON WITTKE, P. Use of relationship between blood lactate and running speed to determine the exercise intensity of horses. The Veterinary Record, v.139, n.5, p.108-110, 1996.

HARRIS, P.A.; MARLIN, D.J.; GRAY, J. Plasma aspartate aminotrasferase and creatine kinase activities in thoroughbred racehorses in relation to age, sex, exercise and training. The Veterinary Journal, v.155, n3, p.295-304, 1998.

JAIN, N.C. Schalm's Veterinary Hematology. 4th ed. London: Lea \& Febinger, 1986, 1221 p.

KOWAL, R.J.; ALMOSNY, N.R.P.; CASCARDO, $B$. et al. Avaliação dos valores de lactato e da atividade sérica da enzima creatina quinase em cavalos (Equus caballus) da raça Puro-SangueInglês (PSI) submetidos a teste de esforço em esteira ergométrica. Revista Brasileira de Ciências Veterinárias., v.13, n.1, p.13-19, 2006.

MATSUI, A.; OSAWA, T.; FUJIKAWA, H. et al. Estimation of total sweating rate and mineral loss through sweat during exercise in 2-years old horses at cool ambient temperature. Journal of Equine Science, v.13, n.4, p.109-112, 2002.

McGOWAN, C.; GOLLAND, L.C.; EVANS, D.L. et al. Effects of prolonged training, overtraining and detraining in skeletal muscle metabolites and enzymes. Equine Veterinary Journal, v.34, p.257-263, 2002

McGOWAN, C. Clinical pathology of the racing horse: the role of clinical pathology in assessing fitness and performance in the racehorse. Veterinary Clinics of North America: Equine Practice, v.24, p.405-421, 2008.

McKENZIE, E.C.; ESSER, M.M.; PAYTON,M.E. Serum biochemistry changes in horses racing a multiday endurance event. Comparative Exercise Physiology, v.10, p.215-222, 2014.

PALUDO, G.R.; McMANUS, C.; MELO, R.Q. et al. Efeito do estresse térmico e do exercício sobre parâmetros fisiológicos de cavalos do exército brasileiro. Revista Brasileira de Zootecnia, v.31, n.3, p.1130-1142, 2002.

PICCIONE, G.; GIANNETTO, C.; COSTA, A. et al. Effects of high intensity exercise on serum electrolytes and protein in thoroughbred horses. Magyar Allatorvosok Lapja, v.129, n.4, p.208213, 2007.

PÖSÖ, A.R. Monocarboxylate transporters and lactate metabolism in equine athletes: a review. Acta Veterinaria Scandinavica, v.43, n.2, p.6374, 2002.

PRINCE, A.; GEOR, R; HARRIS, P. et al. Comparison of the metabolic responses of trained Arabians and Thoroughbred during highand low-intensity exercise. Equine Veterinary Journal, suppl.34, p.95-99, 2002.

ROBINSON, E.N. Current therapy in equine medicine. 5th ed. Philadelphia: Saunders, 2003, $960 \mathrm{p}$.

ROSE, R.J.; ILKIW, J.E.; ARNOLD, K.S. et al. Plasma biochemistry in the horse during 3-day- 
event competition. Equine Veterinary Journal, v.12, n.3, p.132-136, 1980.

SABEV, S. Effect of the jumping activity in the course of training exercise on the level of the serum cortisol, blood lactate and heart rate in horses. Trakia Journal of Sciences, v.9, n.1, p.78-82, 2011.

SCHOTT, H. C.; BOHART, G. V.; EBERHART, S. W. Potassium and lactate up take by noncontracting tissue during strenuous exercise. Equine Veterinary Journal, suppl.34, p.532-538, 2002.

SEEHERMAN, H.J. Treadmill exercise testing: treadmill installation and training protocols used for clinical evaluations of equine athletes.

Veterinary Clinics of North America: Equine Practice, v.7, n.2, p.259-269, 1991.

SNOW, D.H.; KERR, M.G.; NIMMO, M.A. et al. Alterations in blood, sweat, urine and muscle composition during prolonged exercise in the horse. Veterinary Record, v.110, n.16, p.377384, 1982.

THOMASSIAN, A.; WATANABE, M.J.; ALVES, A.L.G. et al. Blood concentration of lactate and determination of V4 in Arabian horses during a incremental exercise test performed at a highspeed treadmill. Archives of Veterinary Science, v.10, n.1, p.63-68, 2005.

THOMASSIAN, A.; CARVALHO, F.;

WATANABE, M.J. et al. Atividades séricas da aspartato aminotransferase, creatina quinase e lactato desidrogenase de equinos submetidos ao teste padrão de exercício progressivo em esteira. Brazilian Journal of Veterinary Research and Animal Science, v.44, n.3, p.183-190, 2007.

VOSS, B.; MOHR, E.; KRZYWANEK, H. et al. Effects of aqua-treadmill exercise on selected blood parameters and on heart-rate variability of horses. Journal of Veterinary Medicine: series A, v.9, n.3, p.137-143, 2002.

WILLIAMSON, L.H.; ANDREWS, F.M.; MAYKUTH, P.L. et al. Biochemical changes in three-day-event horses at the beginning, middle and end of Phase $C$ and after Phase D. Equine Veterinary Journal, suppl.22, p.92-98, 1996. 